\title{
Ultrasound-guided fine-needle aspiration cytology of solid pseudopapillary tumor of the pancreas: a tertiary care centre experience
}

\author{
Ram Nawal Rao ${ }^{1 *}$, Preeti Agarwal ${ }^{1}$, Deepti Mishra ${ }^{1}$, Praveer Rai ${ }^{2}$, Shaila Mitra ${ }^{3}$ and Megha Bansal' \\ *Correspondence: rnrao@sgpgi.ac.in

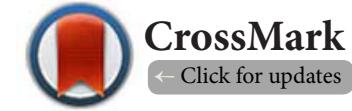 \\ 'Department of Pathology, Sanjay Gandhi Postgraduate Institute of Medical Sciences, Lucknow, UP, India. \\ 2Department of Gastroenterology, Sanjay Gandhi Postgraduate Institute of Medical Sciences, Lucknow, UP, India. \\ ${ }^{3}$ Department of Pathology, BRD Medical College, Gorakhpur, UP, India.
}

\begin{abstract}
Background: Solid pseudopapillary tumours (SPT) of pancreas is an unusual neoplasm with uncertain malignant potential. It is seen predominantly in adolescent girls and young women. We present the clinical, ultrasound-guided fine needle aspiration (US-FNA) cytologic features, differential diagnosis and immunohistochemical findings in SPT.

Methods: A retrospective 4-year (2007-2010) fine needle aspiration samples of 8 solid pseudopapillary tumours of pancreas were reviewed.

Results: The entire cases were cured with exploratory laparotomy. This study includes 8 cases

(1 male, 7 female) of solid pseudopapillary tumours of pancreas. All these cases showed characteristic cytomorphological features displaying hypercellular smears with presence of several papillary fragments lined by multilayered anisomorphic atypical cells having fine chromatin with delicate nuclear groove, myxoid stroma and foamy macrophages in a haemorrhagic background.

Conclusions: Correct preoperative cytological diagnosis of solid pseudopapillary tumours of pancreas may be accurately possible by US-FNA technique and also aids in treatment of the surgically curable cancer in the patients.
\end{abstract}

Keywords: Fine-needle aspiration cytology, ultrasound, cystic, solid pseudopapillary tumour and pancreas

\section{Introduction}

Solid-pseudopapillary tumour of the pancreas (SPT) is a rare uncertain malignant potential tumour which has distinctive cytopathologic features. It is also known as "Frantz tumor" which was first described by Dr. Frantz in 1959 [1]. SPT occurs more frequently in the body and tail of the pancreas of adolescent girls and young women. This tumour can be large and can undergo degenerative cystic changes that are evidenced on clinical and radiographic studies [2]. SPT typically is limited to the pancreas at the time of preliminary diagnosis, and a complete surgical excision is treatment of choice. Metastases are rare after excision, and even patients with metastasis at initial diagnosis often survive for years or decades $[3,4]$. On the contrary pancreatic adenocarcinoma is an aggressive neoplasm. So targeted therapy and chemotherapy have been found to be beneficial in the patients which were highlighted in some studies [5]. Interestingly, IFN- $\beta$ was significantly more effective than IFN- $\alpha$ in inducing cell growth inhibition in pancreatic cancer because it induces a more potent and early cell cycle arrest and apoptosis activation compared with IFN-a [6].

SPT from other pancreatic cystic neoplasms of similar radiologic and cytologic appearance Endoscopic FNA as well as US-FNA can have an important role and provide an accurate preoperative cytodiagnosis, particularly when the USG findings of the mass are inconclusive. US-FNA can differentiate but with different biologic behavior and treatment, such as pancreatic endocrine tumours, acinar cell carcinoma, and papillary mucinous carcinoma [7-13]. SPT behaves like a low-grade malignancy and has an excellent prognosis and hence its differentiation from its other counterparts is important [14]. This study highlights 
Rao et al. Oncology Discovery 2014,

http://www.hoajonline.com/journals/pdf/2052-6199-2-2.pdf

doi: 10.7243/2052-6199-2-2

mainly the cytomorphologic features, differential diagnosis and immunohistochemistry of the cases of SPT diagnosed by US-FNA.

\section{Materials and methods}

This retrospective study in which US guided FNA of pancreatic cases between years 2007-2010 were reviewed. Total number of 150 US guided FNA of pancreas were performed at our institute. Eight out of them were diagnosed as SPT on USguided FNA smears and surgical resection. The clinical details, radiology, cytopathology and histopathology data was retrieved for re-evaluation from the records. US-FNA was performed using 22 gauge needles via a transhepatic (6 cases) or a transgastric ( 2 cases) approach. The aspirated material was quickly smeared into glass slides, air dried, wet fixed in 95\% ethyl alcohol for subsequent Papanicolaou staining and remaining for cellblock (if any). Adequacy of aspirated material was checked under light microscope during the procedures. Immunohistochemical stains for CD10, vimentin, cytokeratins, chromogranin, synaptophysin, neuron-specific enolase and progesterone were performed on 4 cases consisting of surgical resection (two cases) and cellblock samples (two cases). All smears, cell block and tissue sections were reviewed with emphasis on the evaluation of cytomorphologic features and immunohistochemical results. Histopathological tissue sections of all resected specimens were reviewed and findings correlated with those obtained by US-FNA.

\section{Results}

A total of 8 patients with cytological diagnosis of solid pseudopapillary tumours of pancreas were identified. Patients' age ranged from 15 to 47 years. Average tumour size was $5.5 \times 4.5$ to $16.0 \times 15.0 \mathrm{~cm}$ and majorities were located in the pancreatic body and head. Sonologically the tumours were solid in 3 patients (37.5\%), mixed solid and cystic in 4 patients (50.0\%), and cystic in 1 patients (12.5\%). A preoperative diagnosis of solid pseudopapillary tumour was made in 8 patients on the basis of US-FNA cytology. Surgical resection was performed in all cases of SPT.

Patients clinical, USG findings and Cytohistologic findings are summarized in Table 1. The smears showed variable degree of cellularity and characteristically branching papillary fragments in 7 out of 8 cases which composed of vascular stalks with a perivascular amorphous myxoid substance festooned by bland-appearing tumor cells (Figure 1). These tumor cells have variable amounts of scant to moderate cytoplasm with focally projections in some; uniform oval to round nuclei with nuclear grooves, fine chromatin, 1-2 small nucleoli and variable amount of cytoplasm in all cases (Figure 2). The cytology smears also showed areas of necrosis (1 case), mitosis (1 case), cytoplasmic hyaline globules, nuclear groove (7 cases) and cluster of atypical cells with pseudorosette forming structure in 2 cases (Figure 3). In case 5, smear showed prominent large nucleoli in some cells. Some atypical cells have binucleation
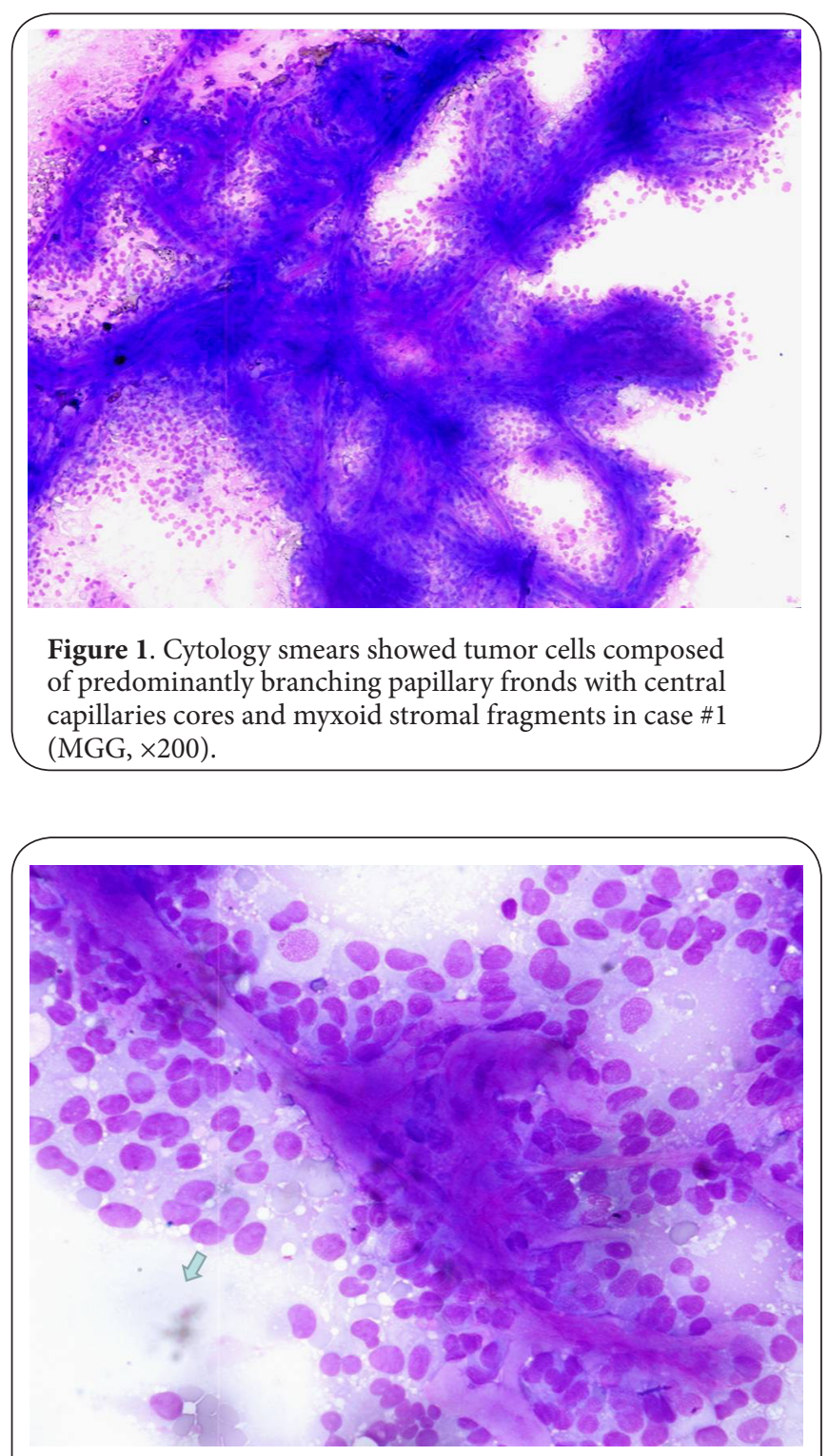

Figure 2. Smears showed tumor cells arranged in pseudopapillary pattern lined by multilayered mildly anisomorphic atypical cells displaying round to oval nuclei with nuclear grooves, fine chromatin and moderate to abundant amount of cytoplasm with characteristic myxoid stroma in case \#1 (MGG, $\times 400)$.

and multinucleation with abundant plasmacytoid cytoplasm ( 2 cases). Background showed areas of haemorrhage (all cases), foam cells ( 5 cases) and cholesterol crystals in 2 cases (Figure 4). 1 of 8 cases US-FNA in cystic mass of the pancreas yielded haemorrhagic fluid and smear shows predominantly myxoid material and occasional singly scattered small to round atypical cells with nuclear groove, fine chromatin and foamy histiocytes. Cytomorphologic findings with histopathologic diagnosis were described in Table 2. Contrast enhancing computed tomography (CECT) were done in all the cases and showed 
Rao et al. Oncology Discovery 2014,

http://www.hoajonline.com/journals/pdf/2052-6199-2-2.pdf

Table 1. Clinical, USG findings and cytohistopathologic diagnosis of SPT (n=8).

\begin{tabular}{|c|c|c|c|c|c|c|c|}
\hline $\begin{array}{l}\text { Case } \\
\text { No } \\
\end{array}$ & Age/Sex & $\begin{array}{l}\text { Tumor } \\
\text { Location }\end{array}$ & Clinical findings & $\begin{array}{l}\text { Tumor } \\
\text { Size }(\mathbf{m m}) \\
\end{array}$ & USG Findings & Surgery & $\begin{array}{l}\text { Cytohistopathologic } \\
\text { Diagnosis }\end{array}$ \\
\hline$\# 1$ & $47 / \mathrm{F}$ & $\begin{array}{l}\text { Head \& } \\
\text { Body }\end{array}$ & $\begin{array}{l}\text { Pain and lump } \\
\text { abdomen, } \\
\text { vomitingx10yrs }\end{array}$ & $110 \times 80$ & $\begin{array}{l}\text { Cystic } \\
\text { Hypoechoic }\end{array}$ & Central Pancreatectomy & SPT \\
\hline$\# 2$ & $21 / \mathrm{F}$ & $\begin{array}{l}\text { Uncinate } \\
\text { process }\end{array}$ & $\begin{array}{l}\text { Pain in abdomen } \\
\text { xlyrs }\end{array}$ & $52 \times 38$ & Solid, calcified & $\begin{array}{l}\text { Pylorus preserving } \\
\text { Pancreaticoduodenectomy }\end{array}$ & SPT \\
\hline$\# 3$ & $27 / F$ & Head & $\begin{array}{l}\text { Pain in abdomen, } \\
\text { Jaundicex6yrs }\end{array}$ & $75 X 53$ & $\begin{array}{l}\text { Solid, cystic } \\
\text { echogenic }\end{array}$ & Central Pancreatectomy & SPT \\
\hline$\# 4$ & $36 / F$ & Head & $\begin{array}{l}\text { Pain in abdomen } \\
\text { x11Yrs }\end{array}$ & $60 \times 50$ & Solid, Echogenic & $\begin{array}{l}\text { Pylorus preserving } \\
\text { Pancreaticoduodenectomy }\end{array}$ & SPT \\
\hline \#5 & $32 / \mathrm{F}$ & Head & $\begin{array}{l}\text { Pain and lump in } \\
\text { Abdomenx3yrs }\end{array}$ & $85 \times 70$ & Solid and cystic & Central Pancreatectomy & SPT \\
\hline \#6 & $25 / \mathrm{M}$ & $\begin{array}{l}\text { Body \& } \\
\text { Tail Mass }\end{array}$ & $\begin{array}{l}\text { Pain in abdomen } \\
\text { Radiating to backx } \\
\text { 4months }\end{array}$ & $50 \times 45$ & Solid Hypoechoic & Pancreaticoduodenectomy & SPT \\
\hline \#7 & $15 / F$ & Head & $\begin{array}{l}\text { Epigastric pain, } \\
\text { Fever \& Vomiting } \\
\text { x3yrs }\end{array}$ & $120 \times 95$ & $\begin{array}{l}\text { Solid and cystic } \\
\text { heterogeneous } \\
\text { Hypoechoic }\end{array}$ & $\begin{array}{l}\text { Central Pancreatectomy, } \\
\text { Spleenectomy }\end{array}$ & SPT \\
\hline$\# 8$ & $25 / \mathrm{F}$ & Tail & $\begin{array}{l}\text { lump and pain in } \\
\text { epigastrium, } \\
\text { Vomitingx } 4 \text { months }\end{array}$ & $160 X 150$ & $\begin{array}{l}\text { Solid and cystic } \\
\text { Hypoechoic and } \\
\text { calcification }\end{array}$ & Pancreaticoduodenectomy & SPT \\
\hline
\end{tabular}

SPT: Solid pseudopapillary tumor of the pancreas

Table 2. Cytomorphologic findings with histopathological correlation $(n=8)$.

\begin{tabular}{|c|c|c|c|c|c|c|c|c|c|c|}
\hline $\begin{array}{l}\text { Case } \\
\text { No }\end{array}$ & $\begin{array}{l}\text { Papillary } \\
\text { Fronds }\end{array}$ & $\begin{array}{l}\text { Central } \\
\text { Capillaries }\end{array}$ & $\begin{array}{l}\text { Myxoid } \\
\text { Stroma and } \\
\text { descrete Cells }\end{array}$ & $\begin{array}{l}\text { Nuclear } \\
\text { Grooves }\end{array}$ & $\begin{array}{l}\text { Amount of } \\
\text { Cytoplasm }\end{array}$ & Necrosis & Mitosis & Backgound & $\begin{array}{l}\text { Cytologic } \\
\text { Diagnosis }\end{array}$ & $\begin{array}{l}\text { Histologic } \\
\text { Diagnosis }\end{array}$ \\
\hline$\# 1$ & + & + & Present & + & Scant & - & - & $\begin{array}{l}\text { Haemorrhagic, Foam } \\
\text { cells \& cholesterol } \\
\text { crystals }\end{array}$ & SPT & SPT \\
\hline$\# 2$ & + & + & Present & + & Moderate & - & - & Haemorrhagic & SPT & SPT \\
\hline \#3 & + & + & Minimal & + & Abundant & - & - & Haemorrhagic & SPT & SPT \\
\hline$\# 4$ & + & + & Present & + & Moderate & - & - & $\begin{array}{l}\text { Haemorrhagic, Foam } \\
\text { cells \& mucin blobs }\end{array}$ & SPT & SPT \\
\hline$\# 5$ & + & + & Present & + & Abundant & - & - & $\begin{array}{l}\text { Haemorrhagic, Foam } \\
\text { cells }\end{array}$ & SPT & SPT \\
\hline$\# 6$ & + & + & Abundant & - & Scant & - & - & Haemorrhagic & SPT & SPT \\
\hline \#7 & + & + & present & + & Abundant & + & Rare & $\begin{array}{l}\text { Haemorrhagic, Foam } \\
\text { cells }\end{array}$ & SPT & SPT \\
\hline$\# 8$ & - & + & + & + & $\begin{array}{l}\text { Moderate } \\
\text { to } \\
\text { abundant }\end{array}$ & - & - & $\begin{array}{l}\text { Haemorrhagic, Foam } \\
\text { cells \& cholesterol } \\
\text { crystals }\end{array}$ & SPT & SPT \\
\hline
\end{tabular}

SPT: Solid pseudopapillary tumor

a large heterogeneous circumscribed solid and solid-cystic mass in head, body and tail regions of the pancreas (Figure 5).

Histopathological examination were done in all eight cases and showed similar microscopic findings. Outer surface of gross specimen showed well circumscribed mass having variegated solid to cystic cut surface with areas of haemorrhage and necrosis (Figure 6). Tumour cells arranged in papillary fronds, sheets and cords around delicate fibrovascular septae (Figure 7). These cells were small to medium size displays uniform round to oval nuclei with groove, fine chromatin and mild to moderate cytoplasm. Marked degenerative changes were also seen in all the cases. Immunohistochemistry was performed only in four cases and results showed strong positivity for CD10 (Figure 8) and vimentin, cytokeratin and focal positivity for synaptophysin, 

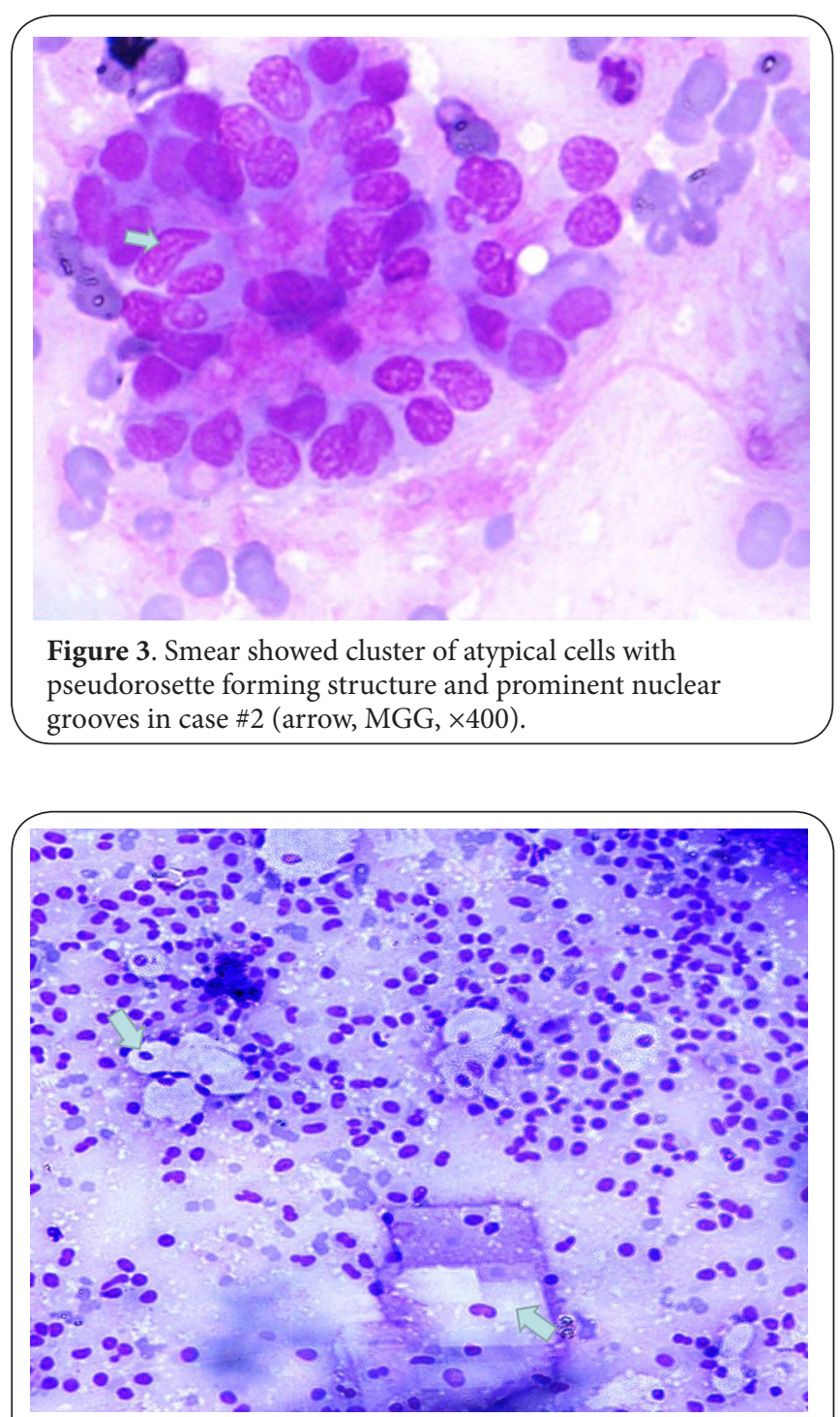

Figure 4. Smear showed singly lying atypical cells with eccentric nuclei, fine chromatin, small 1-2 conspicuous nucleoli, bi/multinucleation, foam cells (up arrow), cholesterol crystal (down arrow) and abundant plasmacytoid cytoplasm misleading to those of pancreatic endocrine tumors in case \#8 $(\mathrm{MGG}, \times 200)$.

neuron-specific enolase (NSE) and progesterone receptors. These immunohistochemical stain results were consistent with previously described immunohistochemistry of the solid peudopapillary tumour of the pancreas.

\section{Discussion}

Solid pseudopapillary tumour of the pancreas (SPT) is very rare tumour with low malignant potential having a distinctive clinicopathological profile $[\mathbf{1 5 , 1 6 ]}$. SPT is most commonly seen in young women with a mean age of 27 years (range, 2-81 years). It is rare in men pediatric population [17-20]. Similarly our study showed female dominance with average

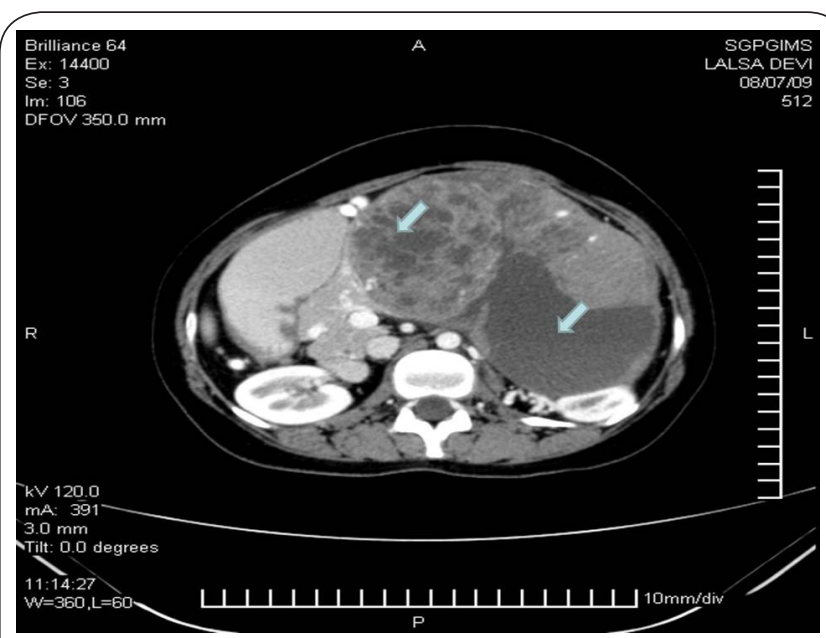

Figure 5. Contrast enhancing computed tomography (CECT) showed a large heterogeneous circumscribed solid-cystic mass (arrow) in body and tail regions of the pancreas in case \#8.

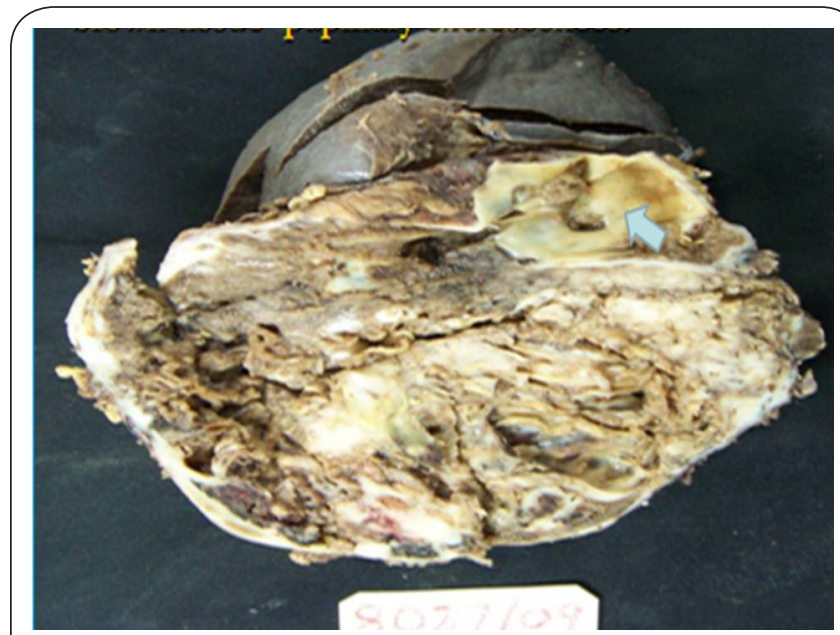

Figure 6. Pancreatic tail mass measuring $16 \times 14 \times 10 \mathrm{cms}$ in size and showing encapsulated-firm variegated solid cystic (arrow) friable grayish white to grayish brown areas with papillary excrescences, hemorrhage and necrosis in case \#8.

age of 27.25 years. Clinical symptoms of the patients usually present on and off abdominal pain in epigastrium and palpable abdominal mass with compression of adjacent organs when the mass is large. In one case of the patient also showed symptoms of vomiting, jaundice and anorexia. Thus, a cystic mass in the pancreas of a young woman raises a clinical suspicion for SPT. Out of eight cases, five of them showed cystic component on ultrasound. In most patients, the tumour follows an indolent clinical course, and complete resection often is curative. However, approximately $10 \%$ to $15 \%$ of SPT are malignant and show local infiltration, recurrence, or distant metastasis $[\mathbf{2 1 , 2 2 ]}$. SPT with malignant behaviour seems more prevalent in the pediatric population, it has been 


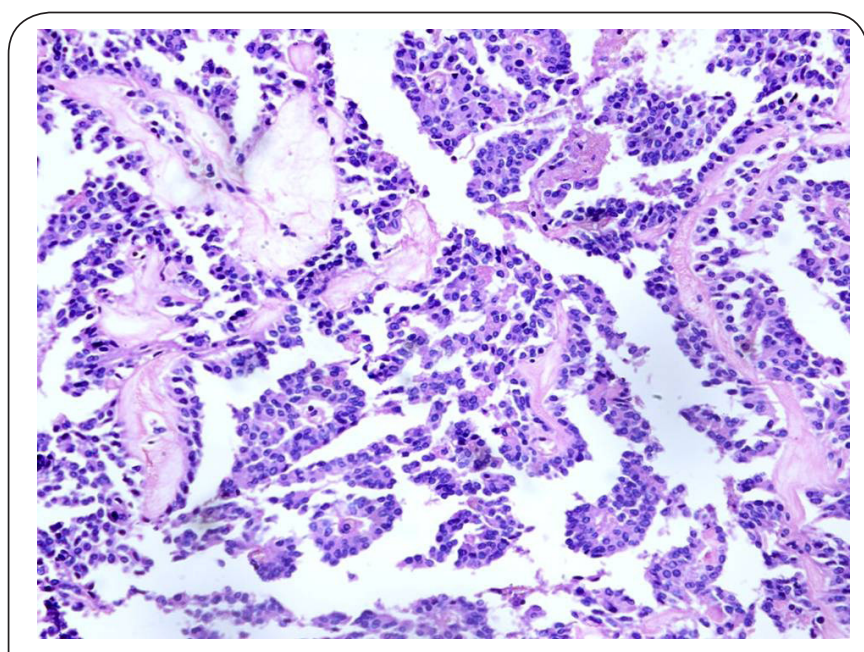

Figure 7. Histopathology section showed tumour arranged in papillary fronds, sheets and cords around delicate fibrovascular septae. Tumour cells were small to medium size displays uniform round to oval nuclei with grooves, fine chromatin and mild to moderate cytoplasm with marked degenerative changes in case \#8 (H\&E, x400).

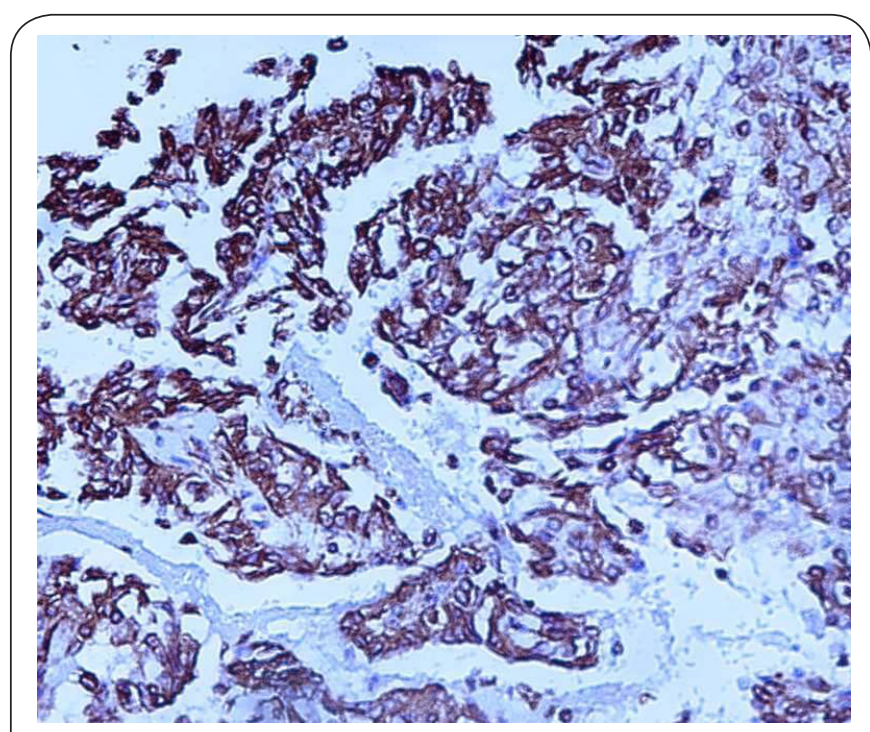

Figure 8. Tumor cells are strongly positive for $\mathrm{CD} 10$ on immunohistochemical staining in case \#8 (IHC CD10, x400).

found in older men and also has indolent behavior $[\mathbf{2 3}, \mathbf{2 4}]$. The benign-appearing SPT might contrast with the cellular anaplasia present in the metastatic deposits [25]. Thus, there are no histologic features that can predict aggressive clinical behavior. Proposed pathologic features related to aggressive behavior or metastatic potential include diffuse growth pattern, venous invasion, nuclear pleomorphism, mitotic rate, necrosis, and areas of dedifferentiation [26].

Imaging studies of SPT show a well-circumscribed, hetero- geneous, solid and cystic mass with sometimes calcification and have often central cystic degeneration. Similarly, tumoral calcification can be seen in the often cystic and nonfunctional large pancreatic endocrine tumor, serous cystadenoma, and mucinous cystadenocarcinoma and less commonly in ductal adenocarcinoma [27]. Two of our cases showed calcification. Thus, image diagnosis is not specific [28]. EUS permits a better evaluation of SPT, but the findings also are not specific. The majority of preoperative diagnoses of SPT have been made by percutaneous approach via EUS or US-FNA techniques. These US-FNA cytomorphologic features are highly characteristic and distinct from those of other cystic or solid tumors of the pancreas [29].

US-guided FNA diagnosis of SPT is simple, accurate and cost effective technique. In most of our SPT cases, US-FNA cytology smears showed numerous isolated branching papillaroid fronds with capillaries having multilayered mildly anisomorphic round to oval atypical cells displaying nuclear groove, fine chromatin, scant to moderate cytoplasm alongwith myxoid stroma, foamy histiocytes, occasional bi/multinucleated cells, cellular debris, psammoma bodies and eosinophilic cytoplasmic hyaline globules on a hemorrhagic background. These hyaline globule are periodic acid-Schiff-positive with diastase-resistant inclusions and similar findings are also described in some previous cases [30-36]. Thus we recommend that when these cytological features are present in the smears,cell block and in combination with immunohistochemical profile, the diagnosis of SPT can be made straight forward. However, pancreatic endocrine tumors, papillary mucinous carcinoma, acinar cell carcinoma and, occasionally, intraductal papillary mucinous tumour and serous cystadenoma must be excluded. In one of our case the US-FNA in cystic mass of the pancreas yielded haemorrhagic fluid and smear shows myxoid material and few singly scattered small to large atypical cells with round to oval eccentric nuclei with nuclear groove in some, fine chromatin and moderate to abundant cytoplasm along withfew foamy histiocytes on the background.

Immunohistochemically, most SPT are immunoreactive for vimentin (vim), a1-antitrypsin, a1-antichymotrypsin [37], occasionally positive for neuron specific enolase and synaptophysin [38] and nonreactive for S-100, CA 19.9 and chromogranin A. In our cases, SPT showed strong expression of vimentin, CD10 alongwith focal for neuron-specific enolase, synaptophysin, progesterone receptors and variable cytokeratin. Lack of expression of epithelial membrane antigen and chromogranin is inconsistent with any of the normal pancreatic cell types and reinforces the epithelial, mesenchymal, and endocrine cell phenotype that suggests a pluripotential embryonic stem cell origin for SPT $[39,40]$. Immunohistochemical detection of progesterone receptors has been found in the neoplastic epithelium of SPT in women but not in men [41].

The main differential diagnoses of SPT includes pancreatic neuroendocrine tumour, acinar cell carcinoma, papillary 
Rao et al. Oncology Discovery 2014,

mucinous carcinoma and intraductal papillary mucinous tumour (IPMT) (Table 3). Pancreatic endocrine tumours mainly occur in older patients and may be associated with a variety of clinical syndromes. Pancreatic neuroendocrine tumours might show similar cytomorphologic features, and, in the absence of papillary structures with perivascular myxoid substance, the distinction between the two is difficult. The presence of rosettes, without papillary structures, occasional multinucleated giant cells, and spackled nuclear chromatin or "salt and pepper" chromatin indicates in favor of a pancreatic endocrine tumour $[42,43]$. Cystic neuroendocrine tumours of the pancreas usually are functional but occasionally might be nonfunctional and are more likely to be confused with SPT on imaging studies [44]. These tumors express neuroendocrine markers such as chromogranin, neuron-specific enolase, and synaptophysin which are usually nonreactive in cases of SPT.

Pancreatoblastoma is a tumour of childhood that lacks the pseudopapillary pattern and fibrovascular stalks with myxoid stroma and consistently is negative for vimentin and positive for pancreatic enzymes, features that allow its distinction from SPT. Acinar cell carcinomas with an endocrine component having immunostains and ultrastructural features of both tumours have been described [42]. Serous cystadenoma showed a well-demarcated solid or cystic mass by EUS and might exhibit prominent papillary differentiation on FNA.

Papillary mucinous carcinoma presents a single, large, often unilocular cystic mass in patients [45]. In compare with SPT, the cells in papillary mucinous carcinoma are columnar with variable nuclear anaplasia, irregular chromatin, and prominent nucleoli [46]. The abundant mucinous background of papillary mucinous carcinoma must not be confused with the myxoid stroma and globoid structures seen in SPT. Thick glistening and viscid mucus material almost always present in intraductal papillary mucinous tumour is an important feature that distinguishes this neoplasm from SPT [47].

Ricardo $\mathrm{H}$ et al., focused on the cytomorphologic features and differential diagnosis of 6 new cases of SPT diagnosed EUS-guided FNA and briefly addressed the recent advances in his understanding of the histogenesis, immunohistochemical analysis, and genetic events of this tumor [48]. Salla et al., reported the clinical, imaging, cytomorphologic features and differential diagnosis of a 17-year-old woman having SPT diagnosed by EUS-guided FNA with a review of the literature in which patient has complaints of an unexplained episodic pain for 2 months and a short history of hypertension. The cytomorphology of the tumor is highly characteristic, with features that are distinctive from those of other cystic and solid tumors of the pancreas [49]. Mehta et al., also described the cytomorphology of solid pseudopapillary tumor of the pancreas and its differential diagnosis in six cases diagnosed preoperatively on US- FNA [50].

An accurate FNA diagnosis will alter the eagerness of patient and surgeon to a complete resection of the tumour, since recurrence has not been reported after complete local resection. In addition, while surgery might not be different, the diagnosis is important if considering preoperative (neoadjuvant) chemotherapy, radiotherapy, or both for acknowledged carcinoma.

Table 3. Differential diagnosis of solid pseudopapillary tumor of pancreas (SPT).

\begin{tabular}{|c|c|c|c|c|c|}
\hline Features & SPT & $\begin{array}{l}\text { Pancreatic } \\
\text { Endocrine }\end{array}$ & $\begin{array}{l}\text { Acinar Cell } \\
\text { Carcinoma }\end{array}$ & $\begin{array}{l}\text { Papillary } \\
\text { Mucinous } \\
\text { Carcinoma }\end{array}$ & IPMT \\
\hline Clinical features & $\begin{array}{l}\text { M/F ratio, } 1: 10 ; \\
\text { young, women; } \\
\text { rare in children }\end{array}$ & $\begin{array}{l}\text { M/F ratio, equal; rare } \\
\text { in children; may be } \\
\text { functional }\end{array}$ & $\begin{array}{l}\mathrm{M} / \mathrm{F} \text { ratio, } 2: 1 \text {; adults; } \\
\text { rare in children and } \\
\text { adolescents }\end{array}$ & $\begin{array}{l}\text { Adult women; } \\
\text { after fifth decade }\end{array}$ & $\begin{array}{l}\text { Adult men; after } \\
\text { sixth decade }\end{array}$ \\
\hline US-FNA findings & $\begin{array}{l}\text { Papillary fronds; } \\
\text { central capillaries, } \\
\text { cell clusters of } \\
\text { variable size }\end{array}$ & $\begin{array}{l}\text { Scattered small cell } \\
\text { clusters; Rosette/acini } \\
\text { formation }\end{array}$ & $\begin{array}{l}\text { Loosely clustered of } \\
\text { atypical acinar cells } \\
\text { with prominent } \\
\text { nucleoli }\end{array}$ & $\begin{array}{l}\text { Papillary frag- } \\
\text { ments; atypical } \\
\text { cell clusters of } \\
\text { variable size }\end{array}$ & $\begin{array}{l}\text { Sparse cellularity; } \\
\text { tight clusters, sheets; } \\
\text { infrequent papillary } \\
\text { clusters }\end{array}$ \\
\hline Myxoid stroma & Present & Absent & Absent & $\begin{array}{l}\text { Mucin instead of } \\
\text { myxoid stroma }\end{array}$ & Thick, viscid mucus \\
\hline Branching fronds & Present & Present & Can be Present & Can be Present & Can be Present \\
\hline Nuclear groove & Present & Absent & Absent & Absent & Absent \\
\hline Necrosis & Rare & May be present & Commonly present & can be present & Present in rare cases \\
\hline \multicolumn{6}{|c|}{ Immunohistochemical study } \\
\hline CD10 & + & $+(20 \%)$ & - & - & - \\
\hline Vimentin & $+(30 \%-50 \%)$ & + & - & - & - \\
\hline Chromogranin & - & + & - & - & - \\
\hline Synaptophysin & $+(30 \%-50 \%)$ & + & - & - & - \\
\hline NSE & + & + & - & - & - \\
\hline Cytokeratin & $+(20 \%)$ & $+(60 \%-80 \%)$ & $+(75 \%-100 \%)$ & + & + \\
\hline Progesterone receptor & + & - & - & - & - \\
\hline
\end{tabular}

SPT: Solid pseudopapillary tumor 
Rao et al. Oncology Discovery 2014,

http://www.hoajonline.com/journals/pdf/2052-6199-2-2.pdf

doi: $10.7243 / 2052-6199-2-2$

\section{Conclusions}

We consider as that US-FNA can present as best cellular yield with an overall diagnostic accuracy and sensitivity for the correct and early cytological diagnosis of SPT. Clinical correlation, imaging findings and cytomorphologic features from US-FNA reach the exact diagnosis of SPT.

\section{Competing interests}

The authors declare that they have no competing interests.

Authors' contributions

\begin{tabular}{|l|c|c|c|c|c|c|}
\hline Authors' contributions & RNR & PA & DM & PR & SM & MB \\
\hline Research concept and design & $\checkmark$ & $\checkmark$ & -- & -- & -- & -- \\
\hline Collection and/or assembly of data & $\checkmark$ & $\checkmark$ & $\checkmark$ & -- & $\checkmark$ & $\checkmark$ \\
\hline Data analysis and interpretation & $\checkmark$ & $\checkmark$ & $\checkmark$ & -- & $\checkmark$ & $\checkmark$ \\
\hline Writing the article & $\checkmark$ & $\checkmark$ & $\checkmark$ & $\checkmark$ & -- & -- \\
\hline Critical revision of the article & $\checkmark$ & $\checkmark$ & -- & $\checkmark$ & -- & -- \\
\hline Final approval of article & $\checkmark$ & -- & -- & $\checkmark$ & -- & -- \\
\hline Statistical analysis & -- & -- & -- & -- & -- & -- \\
\hline
\end{tabular}

\section{Acknowledgement}

We gratefully acknowledge R C Verma, Ram Dulare, R K

Vishwkarma and Sharif Ali, Senior cytotechnologists, at the

Department of Pathology, Sanjay Gandhi Postgraduate Institute of Medical Sciences, for their assistance with data and slides retrieval.

\section{Publication history}

Editor: Giovanni Vitale, University of Milan, Italy.

EICs: Paul J. Higgins, Albany Medical College, USA.

G. J. Peters, VU University Medical Center, Netherlands. William Chi-shing Cho, Queen Elizabeth Hospital, Hong Kong. Received: 12-Feb-2014 Final Revised: 19-Jul-2014

Accepted: 21-Jul-2014 Published: 06-Aug-2014

\section{References}

1. Frantz VK. Tumor of the pancreas. In: Atlas of Tumor Pathology: Fascicles 22 and 28, Section 7. Washington DC: US Armed Forces Institute of Pathology. 1959; 32-33.

2. Washington K. Solid-pseudopapillary tumor of the pancreas: challenges presented by an unusual pancreatic neoplasm. Ann Surg Oncol. 2002; 9:3-4. | Article | PubMed

3. Martin RC, Klimstra DS, Brennan MF and Conlon KC. Solidpseudopapillary tumor of the pancreas: a surgical enigma? Ann Surg Oncol. 2002; 9:35-40. | Article | PubMed

4. Koito K, Namieno T, Nagakawa T, Shyonai T, Hirokawa N and Morita K. Solitary cystic tumor of the pancreas: EUS-pathologic correlation. Gastrointest Endosc. 1997; 45:268-76. | Article | PubMed

5. Vitale G, Zappavigna S, Marra M, Dicitore A, Meschini S, Condello M, Arancia G, Castiglioni S, Maroni P, Bendinelli P, Piccoletti R, van Koetsveld PM, Cavagnini F, Budillon A, Abbruzzese A, Hofland LJ and Caraglia M. The PPAR-gamma agonist troglitazone antagonizes survival pathways induced by STAT-3 in recombinant interferon-beta treated pancreatic cancer cells. Biotechnol Adv. 2012; 30:169-84. | Article | PubMed

6. Vitale $\mathrm{G}$, van Eijck $\mathrm{CH}$, van Koetsveld Ing PM, Erdmann JI, Speel EJ, van der Wansem Ing K, Mooij DM, Colao A, Lombardi G, Croze E, Lamberts SW and Hofland LJ. Type I interferons in the treatment of pancreatic cancer: mechanisms of action and role of related receptors. Ann Surg. 2007; 246:259-68. | Article | PubMed Abstract | PubMed Full Text

7. Brugge WR. Role of endoscopic ultrasound in the diagnosis of cystic lesions of the pancreas. Pancreatology. 2001; 1:637-40. | Article | PubMed
8. Das DK, Bhambhani S, Kumar N, Chachra KL, Prakash S, Gupta RK and Tripathi RP. Ultrasound guided percutaneous fine needle aspiration cytology of pancreas: a review of 61 cases. Trop Gastroenterol. 1995; 16:101-9. | PubMed

9. Nadler EP, Novikov A, Landzberg BR, Pochapin MB, Centeno B, Fahey TJ and Spigland $\mathrm{N}$. The use of endoscopic ultrasound in the diagnosis of solid pseudopapillary tumors of the pancreas in children. J Pediatr Surg. 2002; 37:1370-3. I Article I PubMed

10. Centeno BA. Fine needle aspiration biopsy of the pancreas. Clin Lab Med. 1998; 18:401-27. | Article | PubMed

11. Collins BT and Saeed ZA. Fine needle aspiration biopsy of pancreatic endocrine neoplasms by endoscopic ultrasonographic guidance. Acta Cytol. 2001; 45:905-7. | PubMed

12. Rampy BA, Waxman I, Xiao SY and Logrono R. Serous cystadenoma of the pancreas with papillary features: a diagnostic pitfall on fine-needle aspiration biopsy. Arch Pathol Lab Med. 2001; 125:1591-4. | Article | PubMed

13. Ladanyi M, Mulay S, Arseneau J and Bettez P. Estrogen and progesterone receptor determination in the papillary cystic neoplasm of the pancreas. With immunohistochemical and ultrastructural observations. Cancer. 1987; 60:1604-11. | Article | PubMed

14. Speer AL, Barthel ER, Patel MM and Grikscheit TC. Solid pseudopapillary tumor of the pancreas: a single-institution 20-year series of pediatric patients. J Pediatr Surg. 2012; 47:1217-22. | Article I PubMed

15. Pettinato G, Manivel JC, Ravetto C, Terracciano LM, Gould EW, di Tuoro A, Jaszcz W and Albores-Saavedra J. Papillary cystic tumor of the pancreas. A clinicopathologic study of $\mathbf{2 0}$ cases with cytologic, immunohistochemical, ultrastructural, and flow cytometric observations, and a review of the literature. Am J Clin Pathol. 1992; 98:478-88. | Article | PubMed

16. Mendonca ME, Bivar-Weinholtz J and Soares J. Fine needle aspiration cytology of a solid and papillary epithelial neoplasm of the pancreas. Acta Cytol. 1991; 35:258-60. I PubMed

17. Kloppel G, Maurer R, Hofmann E, Luthold K, Oscarson J, Forsby N, Ihse I, Ljungberg $\mathrm{O}$ and Heitz PU. Solid-cystic (papillary-cystic) tumours within and outside the pancreas in men: report of two patients. Virchows Arch A Pathol Anat Histopathol. 1991; 418:179-83. I Article I PubMed

18. RebhandI W, Felberbauer FX, Puig S, Paya K, Hochschorner S, Barlan M and Horcher E. Solid-pseudopapillary tumor of the pancreas (Frantz tumor) in children: report of four cases and review of the literature. $J$ Surg Oncol. 2001; 76:289-96. | Article | PubMed

19. Ryley NG, Baigrie CF and Buley ID. Papillary and solid neoplasm of the pancreas: fine needle aspiration cytology. Cytopathology. 1994; 5:310-5. | Article | PubMed

20. Snajdauf J, Pycha K, Rygl M, Kocmichova B, Kodet R, Koutecky J and Cumlivska E. Papillary cystic and solid tumor of the pancreas--surgical therapy with the use of CUSA, and a review of the pediatric literature. Eur J Pediatr Surg. 1999; 9:416-9. | Article I PubMed

21. Mao C, Guvendi M, Domenico DR, Kim K, Thomford NR and Howard JM. Papillary cystic and solid tumors of the pancreas: a pancreatic embryonic tumor? Studies of three cases and cumulative review of the world's literature. Surgery. 1995; 118:821-8. | Article I PubMed

22. Gonzalez-Campora R, Rios Martin JJ, Villar Rodriguez JL, Otal Salaverri C, Hevia Vazquez A, Valladolid JM, Portillo M and Galera Davidson $\mathrm{H}$. Papillary cystic neoplasm of the pancreas with liver metastasis coexisting with thyroid papillary carcinoma. Arch Pathol Lab Med. 1995; 119:268-73. | Article | PubMed

23. Jaksic T, Yaman M, Thorner P, Wesson DK, Filler RM and Shandling B. A 20-year review of pediatric pancreatic tumors. J Pediatr Surg. 1992; 27:1315-7. | Article | PubMed

24. Lam KY, Lo CY and Fan ST. Pancreatic solid-cystic-papillary tumor: clinicopathologic features in eight patients from Hong Kong and review of the literature. World J Surg. 1999; 23:1045-50. I PubMed

25. Cappellari JO, Geisinger KR, Albertson DA, Wolfman NT and Kute TE. Malignant papillary cystic tumor of the pancreas. Cancer. 1990; 66:1938. I PubMed 
26. Washington K. Solid-pseudopapillary tumor of the pancreas: challenges presented by an unusual pancreatic neoplasm. Ann Surg Oncol. 2002; 9:3-4. | Article | PubMed

27. Buetow PC, Parrino TV, Buck JL, Pantongrag-Brown L, Ros PR, Dachman $\mathrm{AH}$ and Cruess DF. Islet cell tumors of the pancreas: pathologic-imaging correlation among size, necrosis and cysts, calcification, malignant behavior, and functional status. AJR Am J Roentgenol. 1995; 165:1175-9. | Article | PubMed

28. Furukawa H, Takayasu K, Mukai K, Inoue K, Mizuguchi Y, Ushio K, Takayama T and Kosuge T. Ductal adenocarcinoma of the pancreas associated with intratumoral calcification. Int J Pancreatol. 1995; 17:291-6. | PubMed

29. Pettinato G, Di Vizio D, Manivel JC, Pambuccian SE, Somma P and Insabato L. Solid-pseudopapillary tumor of the pancreas: a neoplasm with distinct and highly characteristic cytological features. Diagn Cytopathol. 2002; 27:325-34. | Article | PubMed

30. Remadi S, Mac Gee W, Doussis-Anagnostopoulou I, Berger SD and Ismail A. Papillary-cystic tumor of the pancreas. Diagn Cytopathol. 1996; 15:398-402. | Article | PubMed

31. Kashima K, Hayashida Y, Yokoyama S, Nagahama J, Sato K, Daa T, Gamachi $A$ and Nakayama I. Cytologic features of solid and cystic tumor of the pancreas. Acta Cytol. 1997; 41:443-9. | Article | PubMed

32. Katz LB and Ehya H. Aspiration cytology of papillary cystic neoplasm of the pancreas. Am J Clin Pathol. 1990; 94:328-33. | Article | PubMed

33. Pelosi G, lannucci A, Zamboni G, Bresaola E, lacono C and Serio G. Solid and cystic papillary neoplasm of the pancreas: a clinico-cytopathologic and immunocytochemical study of five new cases diagnosed by fine-needle aspiration cytology and a review of the literature. Diagn Cytopathol. 1995; 13:233-46. | Article | PubMed

34. Jayaram G, Chaturvedi KU, Jindal RK, Venugopal S and Kapoor R. Papillary cystic neoplasm of the pancreas. Report of a case diagnosed by fine needle aspiration cytology. Acta Cytol. 1990; 34:429-33. I PubMed

35. Mandrekar SR, Pinto RG, Patil R, Vernekar J, Palyekar S and Nadkarni N. Solid and papillary epithelial neoplasm of the pancreas. Report of a case with diagnosis by fine needle aspiration cytology. Acta Cytol. 1997; 41:1823-7. | PubMed

36. Naresh KN, Borges AM, Chinoy RF, Soman CS and Krishnamurthy SC. Solid and papillary epithelial neoplasm of the pancreas. Diagnosis by fine needle aspiration cytology in four cases. Acta Cytol. 1995; 39:489-93. I PubMed

37. Liu X, Rauch TM, Siegal GP and Jhala N. Solid-pseudopapillary neoplasm of the pancreas: Three cases with a literature review. Appl Immunohistochem Mol Morphol. 2006; 14:445-53. | Article | PubMed

38. Bardales RH, Centeno B, Mallery JS, Lai R, Pochapin M, Guiter G and Stanley MW. Endoscopic ultrasound-guided fine-needle aspiration cytology diagnosis of solid-pseudopapillary tumor of the pancreas: a rare neoplasm of elusive origin but characteristic cytomorphologic features. Am J Clin Pathol. 2004; 121:654-62. | Article | PubMed

39. Ferlan-Marolt V, Pleskovic $L$ and Pegan V. Solid papillary-cystic tumor of the pancreas. Hepatogastroenterology. 1999; 46:2978-82. | PubMed

40. Yamaue $H$, Tanimura $H$, Shono $Y$, Onishi $H$, Tani $M$, Yamoto $H$, Kinoshita $\mathrm{H}$ and Uchiyama K. Solid and cystic tumor of the pancreas: clinicopathologic and genetic studies of four cases. Int J Pancreatol. 2000; 27:69-76. | Article | PubMed

41. Kosmahl M, Seada LS, Janig U, Harms D and Kloppel G. Solidpseudopapillary tumor of the pancreas: its origin revisited. Virchows Arch. 2000; 436:473-80. | Article | PubMed

42. Collins BT and Saeed ZA. Fine needle aspiration biopsy of pancreatic endocrine neoplasms by endoscopic ultrasonographic guidance. Acta Cytol. 2001; 45:905-7. | PubMed

43. Lam KY and Lo CY. Pancreatic endocrine tumour: a 22-year clinicopathological experience with morphological, immunohistochemical observation and a review of the literature. Eur J Surg Oncol. 1997; 23:36-42. | Article | PubMed

44. Schwartz RW, Munfakh NA, Zweng TN, Strodel WE, Lee E and Thompson NW. Nonfunctioning cystic neuroendocrine neoplasms of the pancreas.
Surgery. 1994; 115:645-9. | Article | PubMed

45. Solcia E, Capella C, Kloppel G. Tumors of the exocrine pancreas. In: Tumors of the Pancreas. Washington, DC. Armed Forces Institute of Pathology. 1997; 31-144.

46. Hara $\mathrm{H}$, Suda $\mathrm{K}$ and Oyama T. Cytologic study of noninvasive intraductal papillary-mucinous carcinoma of the pancreas. Acta Cytol. 2002; 46:51926. | Article | PubMed

47. Stelow EB, Stanley MW, Bardales RH, Mallery S, Lai R, Linzie BM and Pambuccian SE. Intraductal papillary-mucinous neoplasm of the pancreas. The findings and limitations of cytologic samples obtained by endoscopic ultrasound-guided fine-needle aspiration. Am J Clin Pathol. 2003; 120:398-404. | Article | PubMed

48. Bardales RH, Centeno B, Mallery JS, Lai R, Pochapin M, Guiter G and Stanley MW. Endoscopic ultrasound-guided fine-needle aspiration cytology diagnosis of solid-pseudopapillary tumor of the pancreas: a rare neoplasm of elusive origin but characteristic cytomorphologic features. Am J Clin Pathol. 2004; 121:654-62. | Article | PubMed

49. Salla C, Chatzipantelis P, Konstantinou P, Karoumpalis I, Pantazopoulou $A$ and Dappola V. Endoscopic ultrasound-guided fine-needle aspiration cytology diagnosis of solid pseudopapillary tumor of the pancreas: a case report and literature review. World J Gastroenterol. 2007; 13:515863. | Article | PubMed

50. Mehta N, Modi L, Patel T and Shah M. Study of cytomorphology of solid pseudopapillary tumor of pancreas and its differential diagnosis. $J$ Cytol. 2010; 27:118-22. | Article | PubMed Abstract | PubMed Full Text

\section{Citation:}

Rao RN, Agarwal P, Mishra D, Rai P, Mitra S and Bansal $\mathrm{M}$. Ultrasound-guided fine-needle aspiration cytology of solid pseudopapillary tumor of the pancreas: a tertiary care centre experience. Oncol Discov. 2014; 2:2. http://dx.doi.org/10.7243/2052-6199-2-2 